PEOPLE: International Journal of Social Sciences

ISSN 2454-5899

Fan $\mathcal{E}$ Gu, 2022

Volume 7 Issue 3, pp.120-135

Received: 19th April 2021

Revised: 10 th July 2021, $5^{\text {th }}$ November 2021, $5^{\text {th }}$ January 2022

Accepted: $7^{\text {th }}$ January 2022

Date of Publication: $8^{\text {th }}$ January 2022

DOI: https://doi.org/10.20319/pijss.2022.73.120135

This paper can be cited as: Fan, X. E Gu, Y. (2022). An Analysis of the Status Quo of China's Aid to Pacific Island Countries. PEOPLE: International Journal of Social Sciences, 7(3), 120-135.

This work is licensed under the Creative Commons Attribution-NonCommercial 4.0 International License. To view a copy of this license, visit http://creativecommons.org/licenses/by-nc/4.0/ or send a letter to Creative Commons, PO Box 1866, Mountain View, CA 94042, USA.

\title{
AN ANALYSIS OF THE STATUS QUO OF CHINA'S AID TO PACIFIC ISLAND COUNTRIES
}

\author{
Xuande Fan \\ Student, Research Center for Pacific Island Countries, Liaocheng University, Liaocheng, China \\ fanxuandelib@outlook.com \\ Yuting Gu \\ Student, School of History, Qinghai Normal University, Qinghai, China \\ rickyandguyuting@outlook.com
}

\begin{abstract}
In recent years, with the increase of China's aid to Pacific Island Countries (PIC), the issue of China's aid to Pacific Island countries has become a research hotspot in academic circles, and scholars from various countries have conducted different degrees of research on this. This article is a review article, enumerating some major books and articles for research on this issue. To better understand the research status of scholars from various countries in recent years on this issue, this article uses the literature analysis method to summarize and briefly analyze the main research results of the academic community. After sorting it out, it is found that scholars have different attitudes towards China's aid to Pacific Island countries. Some scholars hold negative views of China's aid, while China's scholars appreciate their aid. Regarding the development trend of this issue, scholars gradually gained a more comprehensive and detailed understanding of China's aid
\end{abstract}


in the region and began to conduct more case studies. This research review can help people quickly understand the current research status of this issue. The article collates scholars' analysis of various aspects of China's aid, such as purpose, impact, and limitations.

\section{Keywords}

China, Pacific Island Countries, Aid, 21st Century

\section{International Scholars' Research on China's Aid to Pacific Island Countries}

With the increase in assistance to PIC, China's influence in the PIC has rapidly increased. China's aid to PIC has become a research hotspot in academic circles in recent years. Some early studies focused on China's influence on the geopolitics of PIC and its relationship with traditional donor countries in this region. Some scholars generally hold a negative attitude towards China's aid.

"Dragon in Paradise: China's Rising Star in Oceania" emphasizes the geopolitical significance of PIC to China (Henderson \& Reilly, 2003). The author believes that a rising China has the characteristics of expansion. China's long-term goal is to eventually replace the United States as a superpower in the Pacific region. China's assistance in the region should be understood from the Pacific or global background. China's assistance to the region is more political than economic. In addition, the author believes that the region has potential military significance for China, such as using these islands to deploy land-based anti-ship missiles to compensate for the weakness of China's navy. The author also mentioned the attitude of the island countries towards China. The author believes that the island countries are playing the "China card" to cooperate with potential US opponents to revive the shrinking aid of Western countries after the Cold War.

"The China syndrome [China's growing presence in the Southwest Pacific.]" also has a negative attitude towards China's aid to PIC (Windybank, 2005). The author believes that China and Taiwan are engaged in a new cold war in this region, which will make the already weak and unstable island government more turbulent and make the entire region more corrupt. China uses unconditional aid, which is mainly used for projects that affect public reputation rather than promote economic development, thereby maximizing its diplomatic influence. The author also uses China's satellite base station in Kiribati to explain China's intention to seek military bases in the Pacific. Besides, the author cites the development of the island countries from geopolitical ambiguity in the 1930s to a strategic area between 1941 and 1945, and then back to relatively 
obscure status, and argues that the strategic significance of the pacific island countries ultimately depends on its participation in the interaction between the major powers.

"Rising Chinese Influence in the South Pacific: Beijing's Island Fever?" introduces China's increasing activities in the PIC and the island countries' response to China (Shie, 2007). Then the author analyzed the various motivations of China in the PIC. First, the author believes that China is a country hungry for resources, and the abundant minerals, fisheries, and timber of the pacific island countries are attractive to China. The author then analyzed the various motivations of China in the pacific island countries. Firstly, the author believes that China is a country hungry for resources, and the abundant minerals, fisheries, and timber of the pacific island countries are attractive to China. Secondly, the author takes the satellite station that China once operated in Kiribati as an example and believes that China regards pacific island countries as an important strategic asset, and China's operations in island countries serve its strategic plan. Thirdly, the author believes that another goal of China is to weaken US alliances in the region to challenge US dominance. China is building long-term strategic alliances by strengthening political and economic partnerships in the pacific island countries. From the standpoint of the United States, the author proposes that the United States should actively develop relations with PIC. The United States can also cooperate more actively with allies in the region such as Australia, New Zealand, Japan, Britain, France, and Singapore to promote good governance and economic development in PIC. The author believes that if the United States continues to remain passive before China's growing power, China may win the PIC.

"China and Taiwan in the South Pacific: Diplomatic Chess versus Pacific Political Rugby" explores the impact of China and Taiwan's aid on pacific island countries and holds a negative attitude towards China and Taiwan's aid in this region (Dobell, 2007). The author believes that the diplomatic competition is undermining the stability of PIC and making this area's politics more corrupt and violent. China and Taiwan are not following the Pacific region's aid rules. The author believes that the diplomatic competition between China and Taiwan is raising the stakes in Pacific politics, especially in Melanesia, making local society cruel and bloody. China is abusing its privileges as a regional leader and gaining local influence through relatively inexpensive measures such as official visits and the construction of public facilities. Apart from its diplomatic status, China is not interested in island state governance. Taiwan rarely really pays attention to the social 
stability of the pacific island countries. The Taiwanese government's funds have caused the Solomon Islands to fall into chaos twice.

In the early days of China's growing influence on island countries, some scholars expressed their concerns about China, including assistance to promote corruption and instability in local society, and challenging the status of traditional donor countries in the region. With the normalization of China's aid to PIC, scholars have acquired more data on China's aid in this region, and thus put forward a more realistic view, and their suspicion of Chinese aid has been eased to a certain extent.

"China: Stumbling Through the Pacific" introduces China's assistance to the PIC from 2005 to 2007 (Hanson, 2009). In addition to containing and eliminating Taiwan's influence in this region, the author believes that China almost does not have a comprehensive grand strategy to guide its aid in this region. The long-term competition between China and Taiwan leads to the tendency of China to pursue short-term goals, take short-term measures, and lack a coherent strategy. The author also raised doubts about China's aid, believing that the aid is unstable and does not consider the recurring cost. The opacity of aid project data has caused suspicion by local governments and other donor countries. The author suggests that China should take advantage of the opportunity brought about by the diplomatic truce with Taiwan to develop long-term aid projects in pacific island countries, which will not only benefit the island countries but also better serve China's national interests and make aid more stable. The author suggests that China should include renewal costs and maintenance costs into its assistance and increase the job opportunities of local workers and increase the transparency of its aid to reduce the debt burden of recipient countries.

Wesley-Smith also holds a positive view of China's assistance in this region, the author's article "China in Oceania: New Forces in Pacific Politics" analyzes the reasons for China's assistance in this region, the author believes that China is paying more and more attention to the pacific island countries (Wesley-Smith, 2007). China's assistance in this area is not only motivated by economic interests but also out of political interests, to strengthen China's voice in international organizations. The author opposes the view that China uses the vulnerabilities of the PIC to gain influence, and that its activities contribute to corruption and instability in the region. The author believes that China neither intends to challenge the global political status quo nor does it intend to play a leading role in Oceania. On the other hand, the author believes that the status of island 
nations in China's strategic plans is relatively vague because they are not close to important transPacific commercial or military sea routes. The author believes that China's growing influence in Oceania is due to the participation of Western countries, not their neglect. The author believes that China's aid model has a positive effect on island countries, and untied aid is welcomed by island countries; China has also expanded the range of options for island countries.

Another article by the author "China in Oceania: Reshaping the Pacific?" discusses China's purpose in the Pacific (Wesley-Smith, 2010). The author believes that the main reason for China's participation in Pacific affairs is to promote its economic development. But on the other hand, the author believes that economic factors cannot explain all of China's policies in this region. The author believes that in the past 20 years, China's primary goal in the region is to build political influence in island countries to support Beijing's interests in international organizations. The author summarizes the purpose of China's aid activities in this region, which is to quell the international community's criticism of its human rights record, promote its economic goals in organizations such as the World Trade Organization (WTO), prevent Japan from playing a greater international role, isolating Taiwan, and Release a "moral debt" that will be cashed at any time in the future. The author praised China's assistance in this region, believing that the assistance has promoted the development of the island country's infrastructure and improved the skill level of local workers. The article also touches on the relationship between Chinese aid and traditional donors and believes that China's growing influence may weaken the influence of Western countries in the region, especially Australia and the United States. The hegemony of former traditional donors in the region is undermining. The article also touches on the relationship between China and traditional donor countries. The author believes that China's growing influence may weaken the influence of Western countries such as Australia and the United States in the region and undermine their hegemony in the region.

The author's article "China's Rise in Oceania: Issues and Perspectives" also analyzes the reasons for China's involvement in Pacific Island countries (Wesley-Smith, 2013). The author believes that Beijing's policy on pacific island countries is not driven by strategic competition with the United States and Taiwan, nor is it the pursuit of a series of specific interests centred on natural resources. It is best understood as part of China's wider contacts with developing countries. The author believes that China's rise is generally welcomed by the leaders of the island countries, believing that China provides island countries with economic and political opportunities that are 
not available under the established power and influence structure, and affirms the positive significance of Chinese aid to PIC.

Yang, J also supports China's assistance in the pacific island countries. The author's "China in the South Pacific: hegemon on the horizon?" explains that China has used aid and other means to enhance its influence in pacific island countries (Yang, 2009). The author believes that the growth of China's influence in the PIC will not replace the West as the dominant force in the region, and the rise of China in the region will not pose a major threat to the West. The author believes that there is no clear evidence that China's participation in pacific island country affairs is a strategic measure related to military security. At present, pacific island countries have only limited military strategic value for China's national security. In the next few years, China still lacks military capabilities to challenge the region's Western countries headed by the United States. At the same time, the author points out that it is of strategic significance for China to develop relations with PIC, which can serve China's long-term development strategy. The author believes that China's influence in the region is not deeply entrenched and is largely based on its unconditional aid and its growing economic interaction with the region. On the other hand, the author also points out China's current problems in the region, namely, it has a serious image problem in the region, which is unlikely to be solved shortly. The author believes that China has neither hard power nor soft power in the pacific island countries to become the hegemon of the region.

In another article "The Pacific islands in China's Grand Strategy: The small States, Big Games", the author points out from the perspective of grand strategy that although China has rapidly increased its influence in pacific island countries through aid and other channels, China's presence in the region should not be understood as driven by traditional military security strategies (Yang, 2011). The author believes that pacific island countries are far away from the Taiwan Strait and have limited military value to China. There is any pacific island country close to China's strategic sea lanes for energy and material trade. Therefore, PIC has only limited value to China's national security strategy. There are indeed military ties between China and some PIC, but they are all for logistical cooperation. They are far from military alliances and are not enough to pose a military threat to Western countries. Secondly, the author believes that the pacific island countries are not very rich in resources, and their role in China is limited. The author analyzes the interests of PIC in China's economy and military and opposing China's existence in the PIC is a "threat." 
"China--Taiwan diplomatic competition and the Pacific islands" examines the aid of both sides in this region from the perspective of China and Taiwan's diplomatic competition in the pacific island countries (Atkinson, 2010). The author believes that the competition between China and Taiwan in the South Pacific is based on "checkbook diplomacy", that is, through diplomatic recognition in exchange for aid. The author looks at the aid projects provided by China and Taiwan to pacific island countries and analyzes how the two sides won and maintain the diplomatic recognition of PIC. The author refutes the high cost of China and Taiwan in exchange for diplomatic recognition of PIC and believes that the two sides are trying to reduce the actual cost of their diplomatic competition. Besides, the amount of assistance that both parties are willing to invest in is limited. From the standpoint of an island country, the author believes that an island country is not a passive victim of China's diplomatic competition with Taiwan, but an active participant. The author holds a relatively neutral attitude towards the diplomatic competition between China and Taiwan in this region.

"China in the pacific: the new banker in town" by based on the continuing diplomatic truce between the mainland and Taiwan, this article reassessed the driving force of China's participation in Pacific affairs and analyzed issues such as the trend of China's assistance (Hanson \& Fliifita, 2010). The author believes that although China is now one of the largest donor countries in the region, its aid bureaucracy is very small, and China lacks a coherent strategy in its aid plans in the region. The primary purpose of China's aid to PIC is to compete with Taiwan, but the author believes that China's aid in the region will be more based on interest considerations rather than competing with Taiwan. Besides, the author believes that although China continues to develop limited military relations with Pacific countries, China's military objectives in the region are still limited.

"Chinese Aid in the South Pacific: Linked to Resources?" explores whether China's aid to PIC is aimed at obtaining local resources (Brant, 2013). The author analyzes China's aid plans and examines the goals and mechanisms of China's foreign aid, and its relationship with commercial interests and resource acquisition. The author believes that China's aid to PIC is not part of the resource transaction so far, and access to resources is not the primary goal of China's assistance to the region. But the author believes that China's aid and national interests are closely linked, which is different from traditional aid countries. 
"Chinese Assistance in the Pacific: Agency, Effectiveness and the Role of pacific island Governments" takes as an example the countries where China has a large aid in the PIC and explores how the governments of the PIC negotiate and supervise the implementation of China's official development assistance (Dornan \& Brant, 2014). The author compares and finds that how the governments of various island countries monitor and implement aid projects vary greatly, and this is an important factor in determining the effectiveness and impact of China's aid. The author believes that many factors will affect the scale and nature of China's aid to the Pacific in the future, and the political dynamics within each island country play a key role in the scale and type of China's aid. The author also emphasizes the important role of Chinese contractors in project delivery and negotiation and poses challenges to the governments of PIC and the Chinese government in terms of supervision, potential corruption, and damage to reputation. The author believes that China can sum up its experience in aid to improve the aid process, regard the trilateral cooperation project as an important pilot, and implement the supervision and planning of the aid project locally.

"Trending with the dragon: Chinese trade, investment, and development assistance in the pacific islands" by K Hannan and S Firth from the perspective of the PIC, author believes that a small part of China's foreign investment flows to the Pacific islands, but this has had a considerable impact on the PIC (Hannan \& Firth, 2015). These small island countries urgently need overseas investment and are highly dependent on development assistance. Therefore, they are particularly vulnerable to the influence of external aid countries.

Zhang's attitude towards China's aid is also relatively positive. In the article "Why to cooperate with others? Demystifying China's trilateral aid cooperation", the author focuses on China's trilateral assistance in pacific island countries, focusing on the China-US trilateral assistance cooperation (Zhang, 2017). The author believes that China is increasingly emphasizing its increasingly important position in the field of development, using trilateral cooperation to establish its global image; China's 40-year foreign exchange has promoted the transformation of its aid cooperation concept, which has prompted its attempts to increase aid performance. The author believes that China hopes to reduce US criticism of China's aid practices through trilateral aid cooperation with the United States, which is conducive to establishing China's image as a responsible power. 
In the article "China in Pacific Regional Politics", the authors believe that China's aid has some advantages (Zhang\& Lawson, 2017). Traditional donor countries have limited aid conditions and strict approval and supervision procedures, while China's aid negotiation and implementation are faster. This approach gives the PIC government more self-determination in the use of Chinese aid. Regarding the purpose of China's assistance in this region, the author believes that China has strategic interests in the Pacific region, however, it is busy with the South China Sea, and it has no time to expand its military power in the PIC.

In the article "Dragon versus Elephant: A Comparative Study of Chinese and Indian Aid in the Pacific", the authors compare China and India's aid to Pacific Island countries (Zhang\& Shivakumar, 2017). The author believes that China is steadily experimenting with trilateral partnerships in the region. Both China and India are increasing their diplomatic investment in pacific island countries to increase their influence as emerging powers. The rise of the two countries in the region has brought opportunities for trilateral aid cooperation. In addition, the author believes that with the increasing influence of the two emerging donor countries in the Pacific region, traditional donor countries have begun to pay more attention to trilateral cooperation with China and India.

"Gifts that Bind: China's Aid to the pacific island Nations" believes that China is trying to improve its aid to Pacific Island countries, which reflects China's image as a "responsible power" and has begun to pay attention to the supervision of the international community (Bozzato, 2017). However, the author believes that China will not become a donor country like Western countries. Out of consideration of China's status as a developing country and the success of China's aid model, its aid will retain obvious "Chinese characteristics". It also includes a certain degree of opacity.

"Ocean of debt? Belt and Road and debt diplomacy in the Pacific" discuss whether China's aid to Pacific Island countries will cause island countries to fall into a debt trap. According to the author's analysis, China does not intend to engage in this kind of debt diplomacy in the Pacific, but the author points out that China's current loan scale is huge and lacks a strong institutional mechanism to protect the sustainability of the recipient country's debt (Rajah et. al., 2019). This also poses a great risk to the fragile economy of island countries.

The author believes that if China wants to continue to play a major role in the pacific island countries without being protected from critics' accusations of a "debt trap," it will need to adjust 
its aid measures. The author compares China's and Australia's aid and believes that Australia's relatively modest infrastructure loan program is more sustainable. At the same time, the author believes that the pacific island countries have the opportunity to seek more favorable funding from external partners, but they must also avoid excessive geopolitical assistance because such assistance puts short-term benefits above the needs of domestic reforms and good governance.

Throughout the past 20 years of international scholars' research on China's pacific island countries, we can discover the changes in scholars' perceptions of the purpose and impact of China's aid. Early studies were mostly skeptical about the purpose of China's aid to PIC. For example, John Henderson and Benjamin Reilly believed that China's aid in this region served China's grand strategy and would eventually replace the hegemony of traditional donor countries in this region. For another example, Susan Windybank believes that Chinese aid is negative to island countries, and diplomatic competition between China and Taiwan in this region will foster corruption in the local government and plunge the local society into chaos.

With the passage of time and the normalization of China's aid to island countries, scholars have changed their perceptions of China's aid to island countries. Regarding the purpose of China's aid, Fergus Hanson believes that China's aid to island countries does not serve as a long-term grand strategy, but a short-term aid mechanism that needs to be improved urgently. Regarding the impact of Chinese aid, scholars such as Terence Wesley-Smith, J Yang, and Denghua Zhang all emphasized the positive aspects of China's aid to island countries, such as providing new aid options for island countries and providing local employment opportunities.

Joel Atkinson also put forward a new point of view on the diplomatic competition between China and Taiwan in the region. He believes that the island countries actively participate in the diplomatic competition between the two sides to gain profits and are not passive victims of the competition between the two sides. In recent years, in response to China's preferential loan assistance model in island countries, some media have put forward the view that "island countries are falling into China's debt trap". Roland Rajah, Alexander Dayant, and Jonathan Pryke of the Lowe Institute have also made some comments on this. According to their research, they believe that China did not intend to drag island countries into a "debt trap."

Regarding the attitudes of international scholars to China's aid, they can be roughly divided into two factions. One is skepticism, such as John Henderson, Benjamin Reilly, and Susan Windybank. These scholars believe that China's aid to island countries will hurt the local area. 
The other is the neutral faction, such as Terence Wesley-Smith, Denghua Zhang and J Yang, and other scholars. They emphasized the advantages of China's aid to the island countries and raised some existing problems of China's aid and the risks to the island countries.

\section{Chinese Domestic Scholars' Research on China's Aid to Pacific Island} Countries

The Chinese academic circles paid attention to China's assistance to pacific island countries relatively late, but as China's assistance plays an increasingly important role in pacific island countries, Chinese scholars have also paid more attention to this issue and achieved some results. Scholars have done various studies on the motivation, mechanism, characteristics, and impact of China's aid in island countries.

A representative book is "International aid to the pacific island countries: A comparative study", The author introduces the overall situation, aid mechanism, and specific cases of China, the United States, Australia, and New Zealand's aid in the pacific island countries (Yu, 2017). It also lists the assistance of international organizations such as the European Union, the United Nations Development Program, and the World Bank to pacific island countries. The author finally made an overall analysis of the international community's assistance to pacific island countries and summarized the effectiveness and deficiencies of the assistance. Although the book covers China's assistance to pacific island countries, it is still at a general level and lacks specific case studies.

Chinese domestic academic journals also discussed the issue of China's assistance to island countries. "The Status Quo, Challenges and Countermeasures of Cooperation between China and pacific island Countries" briefly introduced China's assistance to pacific island countries from a macro level. Cooperation, the author also introduced the difficulties encountered in the process of cooperation between the two parties and put forward suggestions for improving the cooperation between the two parties (Chen, 2011).

"Beyond Competitive Aid: New Thinking on the Construction of the 21st Century Maritime Silk Road and the Economic Development of Pacific Island Countries" believes that the current aid of traditional donor countries in the Pacific Island countries is "competitive" (Qin, 2017) The author believes that this kind of assistance pays more attention to its interests and ignores the interests of island countries. The author believes that China should step out of the 
traditional aid route, cooperate with traditional aid countries, pay more attention to the interests of island countries, and open up new aid routes beyond "competitive aid."

" China’s Climate Aids to South Pacific Countries from Multi-Dimensional Perspectives" examines China's aid to Pacific Island countries from the perspective of climate aid (Kang, 2017). The author also suggests that China should strengthen cooperation and dialogue with international organizations and improve its assistance to island countries.

China's domestic master's degree thesis also has research on China's aid to PIC. "Analysis of China's Foreign Aid to South Pacific Island Countries" explores the mechanism and history of China's aid in island countries from a holistic perspective, and selected Papua New Guinea and Fiji as examples. The author simply proposed the problems and suggestions for improvement in China's aid to Pacific Island countries at this stage are discussed (Kong, 2010).

" Chinese aid to the PIC since the 21st Century--Focus on Papua New Guinea and Fiji" introduces China's aid in Papua New Guinea and Fiji using data from the Lowe Institute and evaluated the characteristics and impact of China's aid to Pacific Island countries (Huang, 2015).

"Research on China's Economic Aid to South Pacific Island Countries" also took Fiji and Papua New Guinea as examples to introduce the mechanism, characteristics, and impact of China's aid in island countries (Ruan, 2019). However, this article mostly quotes Chinese domestic documents and seldom uses international documents, so it is difficult to understand the full picture of the problem.

By investigating the current domestic research status, it is not difficult to find that China's domestic research on China's aid in pacific island countries is relatively weak. Many studies briefly introduce the overall situation of China's aid in this region at the macro level and lack detailed case studies. Some articles have selected some cases to show the details of China's assistance in this area, but the cases used in the articles are similar. Papua New Guinea and Fiji are the majority, but countries with a relatively high proportion of aid to China are rarely involved, such as Tonga, Vanuatu, and Samoa. Chinese domestic scholars are generally supportive of China's aid to pacific island countries and believe that Chinese aid has largely helped the development of Pacific Island countries. 


\section{Conclusion}

Looking back on the research results of the past 20 years, the international academia has conducted meticulous research on China's aid to Pacific Island countries, including a large number of case studies, so the research results are highly credible.

Regarding the analysis of the purpose of China's aid in pacific island countries, the views of scholars in the international academic circle can be roughly divided into three types. Some scholars believe that China's aid in the region is mainly for political purposes, for example, to contain and eliminate Taiwan's influence in this region, challenge the dominance of the United States and its alliances in this region, and enhance its diplomatic influence; representative scholars such as John Henderson, Benjamin Reilly, Susan Windybank and Fergus Hanson. Some scholars believe that China's aid is mainly for economic benefits, such as obtaining mining and fishery resources in the region. Representative scholars such as J Yang. Some scholars believe that China's aid to island countries has multiple purposes. They believe that China's aid in this area is not only for political purposes but also for economic purposes; representative scholars include Tamara Renee Shie, Graeme Dobell, Terence Wesley-Smith and Denghua Zhang, etc. Regarding the analysis of the impact of China's aid in the region, some scholars hold a negative attitude towards China's aid to Pacific Island countries, believing that China's aid to Pacific Island countries makes the regional government more unstable, the society more turbulent, and makes the region more corrupt., Representing scholars such as Susan Windybank and Graeme Dobell. Other scholars believe that China's assistance in the region is constructive, such as providing opportunities for local development and expanding sources of funding for assistance. Representative scholars such as Fergus Hanson, Terence Wesley-Smith, J Yang, and Denghua Zhang. Through the research of international scholars, it can be seen that scholars have made detailed discussions on China's aid in Pacific Island countries, and comprehensive analysis has been made in terms of aid purpose and aid impact.

The research on China's aid to Pacific Island countries is relatively weak in Chinese academic circles, and there is a lack of detailed case studies in terms of the purpose of aid or the meaning of aid. Regarding the purpose of China's aid to island countries, Chinese scholars generally believe that China's aid in the region is altruistic, for the economic development of the island country and the promotion of its international status, at least for mutual benefit and win-win results.; As for the various interest demands behind China itself, Chinese scholars seldom get 
involved. Regarding the impact of China's aid in this region, Chinese scholars also unanimously believe that China's aid is of positive significance to the Pacific Island countries. They believe that China's aid provides a template for the development of island countries and promotes the social progress of island countries. Chinese academic research generally lacks specific cases, only general introductions at the macro level, and a lack of specific data on assistance, partly due to the opacity of government documents.

The limitation of the current study is that official data on China's aid to the Pacific Island countries are not transparent. The future research direction will combine the latest developments of China's aid in the Pacific Island countries and official documents, and based on the data of the Roy Institute, select island countries with a higher proportion of China's aid for case analysis, and further analyze the purpose and influence of China's aid in this region.

\section{REFERENCES}

Atkinson, J. (2010). China-Taiwan diplomatic competition and the Pacific Islands. The Pacific Review, 23(4), 407-427. https://doi.org/10.1080/09512748.2010.495998

Brant, P. (2013). Chinese aid in the South Pacific: linked to resources? Asian Studies Review, 37(2), 158-177. https://doi.org/10.1080/10357823.2013.767311

Chen F. (2011). Status Quo, Challenges, and Countermeasures of Cooperation between China and Pacific Island Countries. Socialist Studies, (05). 123-126. DOI: CNKI: SUN: SHZY.0.2011-05-029.

Dobell, G. (2007). China and Taiwan in the South Pacific: Diplomatic Chess versus Pacific political rugby (pp. 1-19). Sydney: Lowy Institute for International Policy. http://chlold.anu.edu.au/publications/csds/cscsd_op1_4_chapter_1.pdf

Dornan, M. \& Brant, P. (2014). Chinese Assistance in the Pacific: Agency, Effectiveness and the Role of Pacific Island Governments. Asia \& the Pacific Policy Studies, 1(2), 349-363. https://doi.org/10.1002/app5.35

Hannan, K. \& Firth, S. (2015). Trading with the Dragon: Chinese trade, investment, and development assistance in the Pacific Islands. Journal of Contemporary China, 24(95), 865882. https://doi.org/10.1080/10670564.2015.1013377

Hanson, F. \& Fifita, M. (2010). China in the Pacific: the new banker in town. Lowy Institute for International Policy,11(5). https://apo.org.au/node/24501 
Hanson, F. (2009). China: stumbling through the Pacific. Looking North, Looking South: China, Taiwan, and the South Pacific, World Scientific, (26), 104-7. https://doi.org/10.1142/9789814304399_0004

Henderson, J. \& Reilly, B. (2003). Dragon in paradise: China's rising star in Oceania. The National Interest, (72), 94-105. http://www.jstor.org/stable/42897487

Huang Q. (2015). China's aid to Pacific Island countries since the 21st century (Master's thesis, S un Yat Sen University). https://kns.cnki.net/KCMS/detail/detail.aspx?dbname=CMFD201 $\underline{602 \& \text { filename }=1015964394 . n h}$

Kang X. (2017). China's Aids to South Pacific Counties from Multi-Dimensional Perspective, $\begin{array}{llll}\text { Pacific } & \text { Journal, } & 25 & \text { 24-35. }\end{array}$ https://gb.global.cnki.net/kcms/detail/detail.aspx?filename $=$ TPYX201709003\&dbcode $=\mathrm{C}$ $\underline{\mathrm{JFQ} \& \mathrm{dbname}=\mathrm{CJFD} 2017 \& \mathrm{v}=}$

Kong F. (2010). Analysis of China's foreign aid to South Pacific Island countries (Master's thesis, China Foreign Affairs University). https://kns.cnki.net/KCMS/detail/detail.aspx?dbname $=\mathrm{CMFD} 2011 \&$ filename $=2010243879 . \mathrm{nh}$

Qin S. (2017). Beyond Competitive Aid: New Thinking on the Construction of 21st Century Maritime Silk Road and Economic Development of Pacific Island Countries. Pacific Journal, 25(9), 47-56. doi: 10.14015/j.cnki.1004-8049.2017.9.005.

Rajah, R., Dayant, A. \& Pryke, J. (2019). Ocean of debt? Belt and Road and debt diplomacy in the Pacific. Lowy Institute for International Policy. http://www.jstor.org/stable/resrep19796

Ruan Z. (2019). Research on China's Economic Aid to South Taiping Island Countries (Master's thesis, Shanghai Normal University). https://kns.cnki.net/KCMS/detail/detail.aspx?dbnam $\underline{\mathrm{e}=\mathrm{CMFD} 201902 \& \text { filename }=10191217}$

Shie, T. R. (2007). Rising Chinese Influence in the South Pacific: Beijing's “Island Fever”. Asian Survey, 47(2), 307-326. https://doi.org/10.1525/as.2007.47.2.307

Wesley-Smith, T. \& Porter, E. A. (Eds.). (2010). China in Oceania: Reshaping the Pacific? The J ournal of Pacific History, 48(2),231-232. https://doi.org/10.1080/00223344.2013.784538.

Wesley-Smith, T. (2007). China in Oceania: New forces in Pacific politics, https://www.eastwest center.org/publications/china-oceania-new-forces-pacific-politics 
Wesley-Smith, T. (2013). China's rise in Oceania: Issues and perspectives. Pacific Affairs, 86(2), 351-372. https://doi.org/10.5509/2013862351 https://www.eastwestcenter.org/system/tdf /private/pip002_1.pdf?file $=1 \&$ type $=$ node $\&$ id $=32210$

Windybank, S. (2005). The China syndrome [China's growing presence in the Southwest Pacific. ]. Policy: A Journal of Public Policy and Ideas, 21(2), 28-33. https://search.informit.org/d oi/10.3316/ielapa.200506143

Yang, J. (2009). China in the South Pacific: hegemon on the horizon? The Pacific Review, 22(2), 139-158. https://doi.org/10.1080/09512740902815292

Yang, J. (2011). Pacific Islands in China's Grand Strategy. The Pacific Islands in China's Grand Strategy, 127-141.https://doi.org/10.1057/9780230339750_9 